Financial Structures and Monetary Policies in Southeast Asia 
Macmillan International College Editions will bring to university, college, school and professional students, authoritative paperback books covering the history and cultures of the developing world, and the special aspects of its scientific, medical, technical, social and economic development. The International College programme contains many distinguished series in a wide range of disciplines, some titles being regionally biassed others being more international. Library editions will usually be published simultaneously with the paperback editions. For full details of this list, please contact the publishers.

\section{Related titles}

J Wong: ASEAN Economies in Perspective
A Broinowski (ed): Understanding ASEAN
S Ghatak: Monetary Economics in Developing Countries
C Zuvekas: Economic Development - An Introduction
G O Nwankwo: The Nigerian Financial System 


\title{
Financial Structures and Monetary Policies in Southeast Asia
}

\author{
S. Y. LEE \\ National University of Singapore$$
\text { Y. C. JAO }
$$ \\ University of Hong Kong
}

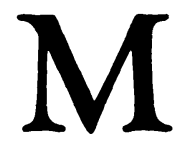


(C) S.Y. Lee and Y.C. Jao, 1982

Softcover reprint of the hardcover 1st edition 1982 978-0-333-28617-3

All rights reserved. No part of this publication may be reproduced or transmitted, in any form or by any means, without permission.

First published 1982 by

THE MACMILLAN PRESS LTD

London and Basingstoke

Companies and representatives

throughout the world

Typeset in Press Roman by

MULTIPLEX techniques ltd., Orpington, Kent

ISBN 978-0-333-28618-0 ISBN 978-1-349-16454-7 (eBook)

DOI 10.1007/978-1-349-16454-7

The paperback edition of this book is sold subject to the condition that it shall not, by way of trade or otherwise, be lent, re-sold, hired out, or otherwise circulated without the publisher's prior consent in any form of binding other than that in which it is published and without a similar condition including this condition being imposed on the subsequent purchaser. 


\section{Contents}

Preface xiii

1 INTRODUCTION 1

2 FINANCIAL STRUCTURE AND MONETARY POLICY IN HONG KONG

Introduction

Financial Structure

Banking and near-banking sectors

Non-bank financial intermediaries

Financial markets

Indicators of financial deepening

Monetary Policy

Currency issue and monetary standard

Determinants and behaviour of money supply

Interest rates and exchange rates

Credit creation and credit allocation

Money supply and inflation

Conduct of monetary policy

Conclusions

3 FINANCIAL STRUCTURE AND MONETARY POLICY IN SINGAPORE

Financial Structure

The Monetary Authority of Singapore (MAS) 53

Singapore Currency Board 54

Commercial banks $\quad 55$

Finance companies $\quad 61$

Merchant banks 63

Post Office Savings Bank (POSB) 63 
Central Provident Fund (CPF) 65

Insurance companies $\quad 66$

Other financial institutions 68

Singapore as a financial centre and the Asian Currency Market and Asian Bond Market

Stock Exchange of Singapore

Direct and indirect contribution of financial institutions

General review: problems and prospects

Monetary Policy

Objectives of monetary policy

Instruments of monetary control

Monetary policy in the 1970 s

International aspect of monetary policy

Money, income and balance of payments

Conclusion

4 FINANCIAL STRUCTURE AND MONETARY POLICY IN MALAYSIA

Financial Structure

Bank Negara Malaysia 98

Commercial banks $\quad 99$

Finance companies $\quad 103$

Merchant banks 105

Industrial finance institutions 107

Rural credit and development institutions $\quad 109$

House credit institutions $\quad 111$

Other financial institutions $\quad 112$

The capital market: Stock Exchange of Malaysia 113

General review: problems and prospects 113

Monetary Policy 116

Objectives and instruments of monetary policy 116

Monetary growth, income growth and price change 120

Determinants of money supply and the balance of payments

Conclusion

5 FINANCIAL STRUCTURE AND MONETARY POLICY IN INDONESIA

Historical development and present framework 126 
Bank Indonesia

Commercial banks

Development banks

Development finance corporations and investment finance corporations

Savings banks

Capital market: Jakarta Stock Exchange

Characteristic features, problems and prospects

Monetary Policy

Monetary policy since 1967

Instruments of monetary policy

139

Foreign exchange rate policy

141

Money, income and prices

Conclusion

6 FINANCIAL STRUCTURE AND MONETARY POLICY IN THAILAND

Financial Structure

Bank of Thailand

Commercial banks

Finance and securities companies

Industrial Finance Corporation of Thailand (IFCT) 156

Bank for Agriculture and Agricultural

Co-operatives (BAAC)

Government Savings Bank

Government Housing Bank

Insurance companies

Characteristic features, problems and prospects $\quad 158$

Monetary Policy

General review of monetary policy

Instruments of monetary control and monetary policy since the 1960s

Money, income and balance of payments

Conclusion

7 FINANCIAL STRUCTURE AND MONETARY POLICY IN THE PHILIPPINES

Financial Structure

Central Bank of the Philippines

Commercial banks 
Rural banks

Development banks

Savings banks

Investment houses

Finance companies

184

Other financial institutions

184

General review: problems and prospects

186

Monetary Policy

Monetary system and monetary control

Monetary policy since the 1950 s

191

Money, income and balance of payments

193

Conclusion

196

8 PROBLEMS AND PROSPECTS OF ASEAN

FINANCIAL COOPERATION

Financial Liberalisation and Degree of Dependence on Central Bank Finance

Market Forces and Government Action

Role of Public Sector in Financial System

202

Foreign Banks and Financial Institutions in

Financial System

202

Direction and Guidelines of Lending

204

207

Rural credit and agricultural finance

207

Finance of industries

210

Commercial credit

211

Financial Deepening and Economic Development Projects

Monetary and Banking Relations among ASEAN

Countries

Problems and Prospects of ASEAN Financial

Cooperation

9 CONCLUSION

Hong Kong and Singapore as Financial Centres

Hong Kong and ASEAN in the Perspective of

Regional Development

Statistical Tables 


\section{List of Tables and Figures}

Chapter 2

Figure 2.1 Foreign currency and trade in Hong Konga model

2.1 Number of Banks and Near-banks in Hong Kong 233

2.2 Consolidated Balance Sheet of Licensed Banks, 1969-79

2.3 Consolidated Balance Sheet of Deposit-taking Companies

2.4 Bank Acquisitions in Hong Kong

2.5 Indicators of Financial Deepening

2.6 Changes in Money Stock Attributable to Indicated Determinants

2.7 Seasonally Adjusted Nominal Money Supply 238

2.8 Annual Growth Rates of Money Stock

2.9 Currency Ratio and Money-Income Ratio 239

2.10 Agreed Bank Deposit Rates 239

2.11 Range of Variations for Lending Rates 240

2.12 Annual Growth of Bank Loans and Advances 240

2.13 Sectoral Distribution of Domestic Bank Loans 241

2.14 Annual Inflation Rate in Hong Kong 242

\section{Chapter 3}

Figure 3.1 ECM/ACM Deposit Rates, Average Deposit Rates and Average Lending Rates of Banks in Singapore, 1969-80

3.1 Number of Financial Institutions in Singapore, 1965-80

3.2 Assets and Liabilities of Commercial Banks in Singapore, 1967-79 (end year) 
3.3 Changing Composition of Banks Loans to Nonbank Customers in Singapore, 1967-79 (end year)

3.4 Consolidated Assets and Liabilities of Asian Currency Units, 1968-80

3.5 Asian Bond Issues, 1971-80

3.6 Deposits, Loans and Investments of Financial Institutions, as at end 1979

3.7 Interest Rates of Commercial Banks, Finance Companies and POSB (average rates)

3.8 Money Supply (seasonally adjusted)

3.9 Money/Income Ratios, 1966-80

3.10 Percentage Change of Money and Income, 1967-80

3.11 Balance of Payments and Changes in Currency, M1 and M2, 1967-80

\section{Chapter 4}

4.1 Sources and Uses of Commercial Bank Funds in Malaysia, 1966-79 (end year)

4.2 Direction of Commercial Bank Lending in Malaysia, 1967-79

4.3 Total Assets of the Financial System of Malaysia, 1960, 1970 and 1977

4.4 Outstanding Loans, Investments and Interest Rates of Financial Institutions of Malaysia, as at end 1979

4.5 Deposits and Interest Rates of Financial Institutions in Malaysia, as at end 1979

4.6 Money Supply of Malaysia, 1966-80 263

4.7 Money/Income Ratios of Malaysia, 1966-79 264

4.8 Change in Currency, M1, M2, and M3, GNP at Current and Constant Prices and CPI in Malaysia, 1967-79

4.9 Determinants of Change in Money Supply in Malaysia

4.10 Balance of Payments and Changes in Currency, M1, M2 and M3 in Malaysia 
Chapter 5

5.1 Bank Credits in Rupiah and Foreign Exchange by Groups of Banks

5.2 Bank Credits in Rupiah and Foreign Exchange by Economic Sectors

5.3 Consolidated Balance Sheet of Deposit Money Banks in Indonesia

5.4 Number of Banks and Financial Institutions in Indonesia, March 1979

5.5 State Bank Lending Rates and Percentages of Refinancing Facilities provided by Bank Indonesia, as from January 1978

5.6 Interest Rates on Deposits

5.7 Currency, Demand Deposits and Quasi-money in Indonesia, 1966-80

5.8 Money/Income Ratios of Indonesia, 1966-79 275

5.9 Changes in M1, M2, GNP at Current and Constant Prices and Cost of Living Index in Jakarta

Chapter 6

6.1 Assets and Liabilities of Commercial Banks in Thailand, 1966-79

6.2 Composition of Bank Lending (Loans, Overdrafts and Trade Bills) of Thailand, 1972-9

6.3 Structure of Interest Rates in Thailand (at end period)

6.4 Money, Quasi-money and Net Deposits of

Non-bank Financial Institutions in Thailand

6.5 M1, M2, M3, and Money/GNP Ratios of Thailand, 1965-80

6.6 Percentage Changes in M1, M2, M3, GNP,

Consumer Prices and Balance of Payments, 1966-79

\section{Chapter 7}

Figure 7.1 Demand and Supply of Investable Funds- a model 
7.1 Structure of the Philippine Financial Institutions and their Relative Assets

7.2 Assets and Liabilities of Commercial Banks in the Philippines, 1949-78

7.3 Loans granted by Commercial Banks, Saving Banks and Development Banks to Different Economic Sectors

7.4 Money Supply, and Quasi-money of Deposit Money Banks in the Philippines, 1966-79

7.5 M1, M2, M3, GNP at Current and Constant Prices and Consumer Price Index of the Philippines, 1966-79

Chapter 8

8.1 GNP per Capita and Economic Structures of ASEAN and Hong Kong, 1979

8.2 Total Assets of Commercial Banks in ASEAN Countries, as at end 1978

8.3 Shares of Loans and Deposits of Domestic and Foreign Banks and their Loan/Deposit Ratios in ASEAN Countries, as at end 1978

8.4 Indicators of Financial Deepening in ASEAN Countries 


\section{Preface}

This is a book about the structure of financial institutions, and the modus operandi of monetary policies in six countries in Southeast Asia: namely, Hong Kong, Singapore, Malaysia, Indonesia, Thailand and the Philippines. The purpose and scope of the book is fully explained in Chapter 1 .

As a jointly written work, the division of labour may be briefly described as follows. S. Y. Lee is responsible for Chapters 3-9, while Y. C. Jao is responsible for Chapters 1-2. Throughout the process of writing this book, the two authors have frequently exchanged ideas and discussed their draft chapters with each other, so as to co-ordinate their analysis and presentation as closely as possible.

The book is addressed to the general public, primarily students of economics and finance, businessmen and intelligent laymen interested in the economic and financial affairs of the region. For this reason, the authors have tried to avoid an overly technical approach to the subject. However, it is hoped that specialists in money and finance, as well as experts on Southeast Asian studies, will find material in this book of interest.

S. Y. Lee wishes to thank Dr Lin See Yan, deputy-governor of Bank Negara Malaysia; Dr Arifin Siregar, managing director of Bank Indonesia; Mr Edgardo P. Zialcita, director of Central Bank of the Philippines; Dr Edita A. Tan, professor, University of the Philippines School of Economics; Bank of Thailand; Monetary Authority of Singapore; and numerous bankers, financiers, and government officials in ASEAN for their comments, information and data. The former Nanyang University granted S. Y. Lee some research funds so that he could visit the other four ASEAN countries and Hong Kong to collect data and to interview people. He would like to take this opportunity to express his gratitude. 
xiv Preface

Y. C. Jao is indebted to Professors A. J. Youngson, F.H.H. King, Mo-huan Hsing, and J. S. G. Wilson, Dr T. B. Lin, and $\mathrm{Mr}$ David Li for helpful comments and suggestions for improvement. Needless to say, the authors alone are responsible for whatever errors or omissions that remain.

Sanuary 1981 Y. Lee
Y.C. Jao 